\title{
MACHADO DE ASSIS E GUIMARÃES ROSA: LOUCURA E RAZÃO EM "O ALIENISTA" E "DARANDINA"
}

\section{YUDITH ROSENBAUM}

Universidade de São Paulo

São Paulo, São Paulo, Brasil

Resumo: Pretende-se cotejar o conto "O alienista", de Machado de Assis, inserido em Papéis avulsos (1882), com o conto "Darandina", de Guimarães Rosa, publicado em Primeiras estórias (1962). Ambos abordam, de modos distintos e contundentes, as relações entre o poder e o discurso psiquiátrico. Considera-se, ainda, que Guimarães Rosa tenha dialogado explicitamente com o texto machadiano, assim como fez em sua réplica homônima ao conto "O espelho", também de Machado. A análise, inspirada pela psicanálise freudiana e pelos estudos foucaultianos, sobretudo pelo ensaio A história da loucura na Idade Clássica (1961), percorrerá as afinidades e diferenças entre as narrativas, tendo em vista as estratégias silenciadoras da loucura pela razão.

Palavras-chave: Machado de Assis; Guimarães Rosa; loucura; razão

\section{MACHADO DE ASSIS AND GUIMARÃES ROSA:}

\section{MADNESS AND REASON IN "O ALIENISTA" AND "DARANDINA"}

Abstract: This essay intends to draw a comparison between "O Alienista," a short story by Machado de Assis that belongs to the collection, Papéis avulsos (1882), and Guimarães Rosa's short story "Darandina," published in Primeiras estórias (1962). Both stories discuss the relationship between power and psychiatric discourse, albeit in decisively different fashions. It is suggested that Guimarães Rosa might be making explicit references to Machado de Assis's story, as he had already done in his homonymous response to "O espelho," also by Machado. This study, inspired by Freudian psychoanalysis and the work of Michel Foucault, notably Madness and Civilization (1961), will point out the affinities and differences between the two narratives while focusing on the strategies adopted by reason for keeping madness silent.

Keywords: Machado de Assis; Guimarães Rosa; madness; reason 
$\mathrm{O}$ itenta anos depois de Machado de Assis ter escrito "O alienista", conto que integra o volume Papéis avulsos, de 1882, Guimarães Rosa parece dialogar com seu antecessor no texto "Darandina", de Primeiras estórias, publicado em 1962. Ambos debruçam-se sobre o mesmo tema: o delírio da razão ao tentar enclausurar a loucura ou o fracasso do discurso científico e do poder diante da ameaça da desrazão.

Outros estudos já compararam não só esses mesmos textos em diferentes ângulos, ${ }^{1}$ como também os contos homônimos "O espelho", de Machado e de Rosa, ${ }^{2}$ mostrando a resposta, em chave moderníssima, do autor mineiro ao mestre realista. Ainda que sejam escritores de tempos e estilos tão díspares, seus olhares para o fenômeno humano confluem para desmascarar, cada um a seu modo, os engodos e impasses da razão cientificista, bem como contrapor à dimensão cartesiana do sujeito unitário e consciente uma psique múltipla e contraditória.

Antes mesmo de Freud e Foucault, Machado antevia os riscos do enlouquecimento da razão e a conjunção perversa entre o arbítrio do poder e a ciência positivista. Por sua vez, já em meados do século XX, Guimarães Rosa radicaliza a impossibilidade de delimitar, com o bisturi da lógica, os territórios móveis da sanidade e da loucura, propondo, pelo jogo da linguagem, a desmontagem de modelos e enquadramentos rígidos.

Percorrerei, em leitura comparativa, os dois textos mencionados, tendo em vista alguns encontros e diferenças. A psicanálise e os estudos foucaultianos terão seu lugar nos bastidores da abordagem crítica, sendo o protagonismo entregue à análise textual. Ressalto, ainda, que este ensaio é

\footnotetext{
${ }^{1}$ Ver OLIVEIRA, Guimarães Rosa leitor de Machado, p. 79-91. Devo muito a esse artigo como inspiração inicial para o presente texto.

${ }^{2}$ Ver WISNIK, Psiquê e Psichê: No encontro dos espelhos, p. 141-167, e HOMEM, Reflexos de espelhos. Machado de Assis e Guimarães Rosa: um estudo comparativo. No ensaio de Wisnik, o conto que nos ocupa aqui vem inserido numa dimensão mais ampla da obra machadiana: "A necessidade inerente ao sujeito, pode-se dizer 'doentia', de se ver confirmado pelo olhar do outro, necessidade que se reflete e se entranha na autoimagem através de múltiplas modalidades da ilusão, pulula em situações conhecidas de 'O alienista', 'Teoria do medalhão', 'D. Benedita', 'Verba testamentária'” (p. 143). E na comparação com "O espelho" de Guimarães Rosa, Wisnik afirma que não é descabido postular que o autor mineiro "tenha escrito o conto homônimo para enfrentar a ironia cósmica do Bruxo do Cosme Velho no limite entre as figurações da crença e da descrença. E que tenha continuado o serão filosófico de Santa Teresa ao criar um personagem-narrador que conta a sua experiência de desaparição do espelho que o reflete, em contraposição ao de Jacobina de Machado. Se em ambos os contos o imaginário, entendido como jogo de imagens através do qual se constitui a função do eu, sofre o impacto de um real que o desarma, cada um deles leva a mesma síndrome a consequências distintas, senão opostas, no percurso simbólico de sua narratividade" (p. 142, grifos do autor).
} 
apenas uma parte de uma pesquisa que se pretende maior e que busca aprofundar as formas de representação da loucura e da desrazão em alguns autores do século XX, entre eles Guimarães Rosa e Clarice Lispector. Aqui teríamos somente um começo.

Tomemos "O alienista" como ponto de partida. O enredo é conhecido: Simão Bacamarte, "filho da nobreza da terra e o maior dos médicos do Brasil, de Portugal e das Espanhas", ${ }^{3}$ investido simbolicamente desse status pela Coroa Portuguesa, instala-se na pequena Vila de Itaguaí e inaugura a Casa Verde, sede manicomial onde serão internados os desequilibrados mentais. Afinal, para o renomado doutor, "a razão é o perfeito equilíbrio de todas as faculdades; fora daí insânia, insânia e só insânia". ${ }^{4}$ Já veremos que a exacerbada exigência lógica de Bacamarte para distinguir os sãos dos loucos será a sua própria derrocada. Diz ele ao Sr. Soares, boticário da Vila e seu fiel escudeiro: "- Supondo o espírito humano uma vasta concha, o meu fim, Sr. Soares, é ver se posso extrair a pérola, que é a razão; por outros termos, demarquemos definitivamente os limites da razão e da loucura". ${ }^{5}$

A resposta do Vigário Lopes à sagaz iniciativa do alienista é ainda mais sugestiva: "- Com a definição atual, que é a de todos os tempos, acrescentou, a loucura e a razão estão perfeitamente delimitadas. Sabe-se onde uma acaba e onde a outra começa. Para que transpor a cerca?". ${ }^{6}$

O exercício sistemático do método experimental será levado às últimas consequências pelo zeloso médico Simão Bacamarte, que tomará para si a tarefa de estudar profundamente a loucura, classificar os casos e "descobrir enfim a causa do fenômeno e o remédio universal". 7 Para isso, o alienista constrói uma taxonomia que nada deve aos cientistas botânicos ou zoólogos, expandindo a abordagem positivista das ciências naturais ao domínio das humanidades: "Dividiu-os primeiramente em duas classes principais: os furiosos e os mansos; daí passou às subclasses, monomanias, delírios, alucinações diversas". 8

\footnotetext{
${ }^{3}$ ASSIS, Obra completa, vol. II, p. 253.

${ }^{4}$ Idem, p. 251.

${ }^{5}$ Idem, p. 261.

${ }^{6}$ Ibidem.

${ }^{7}$ Idem, p. 256.

${ }^{8}$ Idem, p. 257.
} 
No início, pelo exame minucioso dos comportamentos observáveis, serão reclusos na casa de Orates os seres defeituosos e desviantes da média sendo esta definida pela estatística da norma. E o que seria o normal, dentro da visão positivista do alienista? Empresto aqui as palavras do crítico Alfredo Bosi, em magistral ensaio sobre Machado: "O normal seria algo de homogêneo repetido ao infinito. O normal é a forma pura da aparência pública, a forma formada, a forma alheia a qualquer movimento interior". ${ }^{9}$

Munido desse pressuposto, o dr. Bacamarte desce a lâmina da ciência na população amedrontada, inicialmente com ajuda do vigário e do boticário, encerrando no asilo qualquer um dotado de alguma excentricidade ou até humanidade explícita, como Costa, um dos cidadãos mais estimados da vila (mas doentiamente generoso, aos olhos do alienista) e em seguida a prima de Costa, que intercedeu pelo parente. Tão logo a Casa Verde passa a abrigar a maioria da população, inevitavelmente distante da tal norma, a coerência racional com o critério estabelecido demanda a sua inversão, e os diferentes (a maioria) se tornam a média normativa. O médico, em seu desvario científico, surpreende-se com essa descoberta: "A loucura, objeto dos meus estudos, era até agora uma ilha perdida no oceano da razão; começo a suspeitar que é um continente". ${ }^{10}$

Em pouco tempo, quase toda a população de Itaguaí acaba reclusa, e o "bom serviço à humanidade", no qual Bacamarte acreditava, transforma-se na "bastilha da razão humana", insuflando a revolta do povo contra o "despotismo científico" do ilustre médico. Ele, que enclausura a própria esposa na Casa Verde, consegue ainda algumas alianças com o poder político para salvar sua invenção da derrocada. Porém, obrigado a rever sua "teoria das moléstias cerebrais" pelas evidências estatísticas, resolve libertar todos os internos do estabelecimento e procurar só aqueles que tivessem "o perfeito equilíbrio mental e moral", sem vícios nem defeitos. E nesse momento, olhando para si mesmo, "[...] pareceu-lhe que possuía a sagacidade, a paciência, a perseverança, a tolerância, a veracidade, o vigor moral, a lealdade, todas as qualidades enfim que podem formar um acabado mentecapto". ${ }^{11}$

${ }^{9}$ BOSI, Machado de Assis: O enigma do olhar, p. 90-91.

${ }^{10}$ ASSIS, cit., p. 260.

${ }^{11}$ Idem, p. 287. 
Se de cientista passara a tirano, de médico passará a louco: "- A questão é científica, dizia ele; trata-se de uma doutrina nova, cujo primeiro exemplo sou eu. Reúno em mim mesmo a teoria e a prática". ${ }^{12}$

Já se sabe o final: sendo ele o único a diferenciar-se pela absoluta idoneidade psíquica e moral - ao menos em sua viciada percepção, corroborada por uma assembleia de amigos -, termina internando-se na Casa que criou e caindo no que Augusto Meyer chamou de "lógica do absurdo" ou o "suicídio da razão". ${ }^{13}$ Entregando-se ao estudo e à cura de si mesmo, morre em dezessete meses, "no mesmo estado em que entrou, sem ter podido alcançar nada". ${ }^{14}$

O colapso do pensamento, refém de si mesmo, encontra em Machado o seu paroxismo. A isso junte-se a megalomania absolutista que visa a descobrir o"remédio universal". Quando aquele que se acha o mais virtuoso (o alienista) coincide com o mais insano, ironia maior do texto machadiano, não há mais como apartar a loucura da razão.

A objetividade absoluta funciona como um "bacamarte", que significa antiga arma de fogo, que destrói, no caso, seu próprio usuário. ${ }^{15}$ Enquanto se busca exorcizar da razão tudo o que dela destoe, ou seja, o inconsciente e suas manifestações tão bem sondadas pela psicanálise - entre elas, as subversões do princípio de identidade e da lógica da não contradição -, ou ainda, enquanto o poético e o onírico não puderem habitar o campo dos possíveis, a hegemonia da razão estará sempre assombrada por si mesma.

Lembremos aqui a proposição de Michel Foucault em sua História da loucura. ${ }^{16}$ Em primeiro lugar, a figura que legitima o poder político na passagem da monarquia para o domínio burguês no século XVIII é a "autoridade médica", que Simão Bacamarte tão bem representa ao ser nomeado pelo rei de Portugal. A ciência médica estará encarregada dos loucos quando a filosofia cartesiana e seu exercício da dúvida metódica tornarem qualquer incerteza ou dubiedade índices de desrazão. ${ }^{17}$ A loucura

\footnotetext{
${ }^{12}$ Idem, p. 288.

13 "No 'Alienista' é a própria atividade mental, é o pensamento como intellectus ipse que entra em cena e, descobrindo o círculo vicioso da sua loucura de ser e de parecer, suicida-se logicamente." (MEYER, Na casa verde, p. 45-47).

${ }^{14}$ ASSIS, cit., vol. II, p. 288.

${ }^{15}$ A sugestão desta ideia e das relações com Foucault vêm, em parte, do artigo de Cecília Orsini sobre "O alienista" em "Nós, os alienistas".

${ }^{16}$ FOUCAULT, A história da loucura na Idade Clássica, 1978.

17 "A Não Razão" do século XVI constituía uma espécie de ameaça aberta cujos perigos podiam sempre, pelo menos de direito, comprometer as relações da subjetividade e da verdade. O percurso da dúvida cartesiana parece testemunhar que no século XVII esse perigo está conjurado e que a loucura foi
} 
será expulsa da filosofia e sobreviverá na arte. Os loucos, que, segundo Foucault, ainda gozavam de uma aura sagrada como os leprosos até o século XVII, serão misturados aos marginalizados e improdutivos quando a lepra desaparece. Com o nascimento dos asilos médicos, no século XVIII, época abordada no conto por Machado, o louco será o doente mental a ser excluído como demente. ${ }^{18}$

O que chama atenção na narrativa machadiana é a aproximação entre os estratagemas teóricos do dr. Bacamarte, em sua cruzada pela sanidade, e as próprias características da insânia que combate. Isso nos remete ao que Freud observa, com assustadora acuidade, em seu ensaio sobre o doente Schreber, a partir de relato escrito pelo próprio paciente. Vale a pena um excurso sobre esse estudo de Freud para tornar mais visível o procedimento, tanto machadiano quanto rosiano, que embaralha as fronteiras entre a ratio e a loucura, já que esse é o elo que permite o cotejo entre as duas narrativas.

Após minuciosa análise do caso Schreber, em que os delírios persecutórios, as fantasias transexuais e megalomaníacas são examinados de modo a revelar suas conexões mais recônditas, Freud estabelece uma rigorosa teorização sobre a função do delírio nas psicoses. E - o que mais nos interessa aqui - faz coincidir em muitos aspectos a sintomatologia verificada em Schreber com traços obsessivos ou paranoicos do próprio fundador da psicanálise... Ao final do ensaio, o quadro clínico analisado e a sua criação teórica são perigosamente aproximados: "O futuro dirá se a teoria contém mais delírio do que eu gostaria ou se o delírio contém mais verdade do que outros acreditam ser possível". ${ }^{19}$

Ao comentar o trabalho de Freud, Renato Mezan explicita o ponto central:

colocada fora do domínio no qual o sujeito detém seus direitos à verdade: domínio este que, para o pensamento clássico, é a própria razão. Doravante, a loucura será exilada. Se o homem pode sempre ser louco, o pensamento, como exercício de soberania de um sujeito que se atribui o dever de perceber o verdadeiro, não pode ser insensato." (FOUCAULT, cit., p. 47, grifos do autor).

${ }^{18}$ Vale lembrar que Luiz Costa Lima, em seu artigo "O palimpsesto de Itaguaí", reflete sobre "O alienista" em chave afim ao que comento aqui. Ele nos remete também a Foucault para mostrar a ideia de loucura vigente na época de Machado. Em sua História da loucura, Foucault comenta duas concepções de loucura que se opunham: de um lado, a visão trágica da loucura, representada nas pinturas de Bosch, Dürer e Brueghel, nas quais a loucura é uma forma sábia de revelação; de outro, a de Erasmo e os humanistas, mostrando a loucura em sua "medíocre verdade" sob o olhar da razão - e que triunfará na Idade Clássica. "Já não se concebe a loucura como o outro lado da razão mas sim como voz que só a razão faz falar", diz Lima. E, mais adiante, o ensaísta afirma: "A personagem [Bacamarte] tinha a segurança da ciência, ao passo que o Machado questionador tomava a loucura menos como uma doença do que como uma linguagem excluída" (LIMA, O palimpsesto de Itaguaí, p. 265).

${ }^{19}$ FREUD, Obras psicológicas completas, v. XIII. 
A questão por ele colocada equivale, portanto, ao seguinte: até que ponto um delírio paranoico se distingue de uma teoria científica? Ou em outros termos, por que a elaboração teórica é diferente do delírio, se ambos se propõem à mesma finalidade: explicar o real? Pois não há dúvida de que para o delirante, o mundo se articula segundo as linhas de força e as categorias inspiradas pelo delírio. [...] Como distinguir então entre um sistema filosófico ou uma teoria científica e um produto da imaginação delirante $?^{20}$

Obviamente, os processos de construção teórica de Freud não devem ser lidos como constructos delirantes, ainda que muitos assim o tenham recebido. O fato é que a teoria - como se vê nas elucubrações teóricas de Simão Bacamarte - pode funcionar como defesa justamente contra a própria psicose, protegendo-se desta pela elaboração racional. A esse respeito, Mezan traz ao debate o livro de François Roustang, Un destin si funeste, no qual o autor busca responder à pergunta "o que é uma teoria psicanalítica?". A resposta de Roustang é machadiana: "a teoria é o delírio de vários, o delírio é a teoria de um só". ${ }^{21}$

Ao assinar embaixo dessa sentença, Machado parece estremecer as fronteiras entre saber científico e insanidade mental, antecipando a modernidade de Rosa.

\section{Lunáticos e terrestres}

Passo agora a comentar comparativamente o conto de Guimarães Rosa, buscando possíveis afinidades e distâncias com Machado.

A ironia fina e demolidora de Machado de Assis transforma-se em humor sensível e desconcertante em "Darandina", 22 que faz girar um fato, em princípio patético e quase trágico, em anedota cômica. Não é a primeira vez que Guimarães Rosa dá lugar a personagens desarrazoados em sua obra. A saber, Primeiras estórias constituem, muito particularmente, a sua própria "História da loucura", contando estórias de seres marginais à tônica hegemônica, errantes ou exilados do status quo social. "Sorôco, sua mãe, sua

\footnotetext{
${ }^{20}$ MEZAN, Freud: pensador da cultura, p. 302.

${ }^{21}$ ROUSTANG, E. Un destin si funeste, apud MEZAN, cit., p. 307.

${ }^{22}$ ROSA, Primeiras estórias, 1988.
} 
filha", "Tarantão, meu patrão", "A menina de lá", "A terceira margem do rio", entre outros, são contos que flagram momentos diversos da consolidação do saber psiquiátrico desvendado por Foucault. ${ }^{23}$

Há estudos críticos importantes sobre essa tópica rosiana. Leyla Perrone-Moisés assim define esse peculiar território geossimbólico em Rosa:

Na obra de Guimarães Rosa, além dos lugares físicos e metafísicos bem estudados pela crítica, são referidos alguns lugares que não são nem físicos, nem metafísicos (não pertencem nem à geografia, nem a um suposto mundo sobrenatural), nem totalmente inventados, nem apenas lembrados (não pertencem à imaginação ou à memória consciente). Esses lugares, que chamei de "nenhures", têm vários traços daquilo que Freud revelou e explorou sob o nome de inconsciente. ${ }^{24}$

"Darandina" apresenta mais um desses espaços inexistentes, metáfora obsedante do que não é passível de inscrever-se em nenhum discurso categorial de qualquer ciência conhecida. Como então situar-nos diante do que não tem nome e está em nenhuma e em toda parte?

Um senhor "de trato, tão trajado" atravessa correndo os portões de um manicômio e acocora-se no topo de uma palmeira. O episódio é narrado por um dos médicos plantonistas do instituto, no qual o homem desvairado viera dar o "ar de sua desgraça" ao tentar internar-se para, segundo ele, garantir seu lugar e tratamento quando a humanidade já enlouquecida um dia buscaria abrigo. A menção ao conto machadiano e sua Casa Verde é clara, ainda que os recursos estilísticos mobilizados por Rosa sejam outros e o final em aberto também, como veremos. Enquanto Machado transita pelo fio do pessimismo ao descartar qualquer lirismo na mente alucinada, o autor mineiro - que atuou como médico no hospital de Barbacena em 1933, após a revolução de 1932 - abre perspectivas diversas sobre o caráter lunático de seu personagem. Além dessa nítida diferenciação, o bruxo do Cosme Velho evita transloucar sua linguagem, operando no lume claro da semântica clássica; já Rosa se compraz em neologismos, provérbios desmanchados e arcaísmos linguísticos para estremecer o vocábulo de sua acomodação.

Vejamos como isso se dá.

O "nenhures" do conto é essa palmeira, "páramo empíreo", "muralhavaz", que recorta uma singular topografia: no espaço celeste, acima

${ }^{23}$ Agradeço à professora Adélia Bezerra de Meneses por esse inspirador insight em conversa recente.

${ }^{24}$ PERRONE-MOISÉS, Para trás da Serra do Mim, p. 210. 
dos terrestres subaéreos, que miram o alto, perplexos, um ilustre homem em surto delira verdades sapienciais como essas, entre tantas: "eu nunca me entendi por gente", "vocês me sabem é de mentira", "viver é impossível", "o amor é uma estupefação". Sem dúvida, nas frases sem sentido outro sentido maior se revela aos seres debaixo, prisioneiros de significações unívocas e habituais.

$\mathrm{Na}$ turba inquieta e curiosa, alternam-se personagens inseridas na hierarquia hospitalar, representantes institucionais e funcionários do governo. Adalgiso, um interno de plantão, Sandoval, o dr. Diretor, de alcunha tautológica, enfermeiros, padioleiros, o dr. Enéias, o dr. Bilolô (nome que brinca com o termo "abilolado", enlouquecido), o professor Dartanhã (outro jogo com a onomatopeia "tantã", relativa a alguém fora de si, além de remeter ironicamente ao herói mosqueteiro), a polícia e o capelão. Igreja, Estado e psiquiatria parecem se embolar no encalço da insensatez. Todos encarregados de garantir a ordem, mas a desordem entre eles é grande. Com eles, a camisa de força pronta para imobilizar o maluco. Aliás, anota o narrador, "nosso não era o nosso homem". Ou seja, a partir de sua voluntária exclusão do mundo ínfero, onde os homens razoáveis se mostram atrapalhados na comédia de erros ao buscarem soluções para o impasse, o que era humano reconhecível passa a ser ente incodificável, não mais "nosso". Somente quando o homem sem razão for percebido como estranho será possível aos de cá da margem reassegurarem seus lugares de equilíbrio. $^{25}$

Oscilante entre idolatrar ou denegrir o "personagente", estando "aquém da torre de marfim", a multidão "tumultroada" aproveita para vaiar autoridades, impedir a clausura do homem e bradar que o doido é um gênio quando este resolve desnudar-se e lançar suas vestes ("bandeiras despregadas") sobre o "desrespeitável público". A cena cômica desvela o quanto a loucura nos desnuda, tirando os véus que nos encobrem. Mas enquanto quem está isolado na palmeira é o outro e não nós, seres sensatos, podemos rir sossegados. ${ }^{26}$

\footnotetext{
25 Remeto o leitor ao artigo "Guimarães Rosa: O canto da desrazão", em que a mesma questão é estudada em outros três contos de Guimarães Rosa, já mencionados: "Sorôco, sua mãe, sua filha", "A menina de Lá" e "A terceira margem do rio". Ver Rosenbaum, 2008, p. 150-158.

${ }^{26}$ Segundo Foucault, "Se a loucura conduz todos a um estado de cegueira onde todos se perdem, o louco, ao contrário, lembra a cada um sua verdade; na comédia em que todos enganam aos outros e iludem a si próprios, ele é a comédia em segundo grau, o engano do engano" (FOUCAULT, cit., p. 14).
} 
Enquanto isso, atarantada diante da situação descontrolada e sem alcançar o sujeito em sua perdição, a autoridade médica se alia às demais forças de ordenação social (a lei policial, o saber científico, o poder local) e encena a sua teatral patologia nomeando diagnósticos para, nas palavras do narrador, "penetrar em o labirinto de um espírito, e - a marretadas do intelecto - baqueá-lo, com doutoridade". ${ }^{27}$ Assim, vemos sucederem-se vãs tentativas de enquadramento e domínio através de nomenclaturas formais mais insanas que a própria insanidade, atribuindo à loucura as máscaras da doença mental, passível de medicalização: "psicose paranoide hebefrênica", "dementia praecox", "síndrome exofrênico de Bleuler", "excitação maníaca" etc. Como em"O alienista", o universo da desrazão é recoberto por etiquetas taxonômicas. Mas no conto machadiano, a Casa Verde se torna um "cárcere privado", sem chance de libertação; já em Rosa, nem médicos, nem bombeiros, nem governador alcançam a palmeira inacessível onde a figura do louco se protege.

Seria preciso, antes de avançar, discriminar melhor os termos "loucura" e "desrazão", tão presentes nesta leitura. Penso que Guimarães Rosa trabalha nos dois polos quando expressa a aventura humana de confinar a desrazão na figura dolouco, ao mesmo tempo em que mostra como essa mesma desrazão é inaprisionável na loucura, espraiando-se para fora de seus limites. $\mathrm{Na}$ esteira de Foucault, o filósofo Peter Pal Pelbart traz um importante esclarecimento sobre essa complexa questão, situando o espaço da desrazão antes da Grande Internação ocorrida na Idade Clássica:

Desrazão, entenda-se, não era esse exterior confinado a um personagem recluso, como o foi a loucura a partir da Idade Clássica, mas simplesmente o Exterior, isto é, o exterior ao homem, e isso sob as mais diversas formas que a história lhe emprestou, seja como Caos do Mundo, Aventura da Linguagem, Estranheza da Natureza, Transcendência do Divino, Fúria da Morte, Sagrado dos Elementos, Bestialidade do Humano etc. Estas são algumas das diferentes maneiras através das quais o homem se relacionou, ao longo da história, com aquilo que não era ele, num vaivém que hoje nos parece quase impensável. É que a modernidade, tornando tudo familiar, aprendeu a

${ }^{27}$ ROSA, cit., p. 130. 
domesticar o Estranho, seja sob o modo da tutela clínica, da dominação técnica ou da oposição antitética. ${ }^{28}$

A esse "Exterior", mostra-nos Pelbart, Maurice Blanchot deu o nome de "o Fora". Foucault teria retomado o termo e forjado a expressão de "o Pensamento do Fora" para abarcar essa relação com o Exterior. Esse "apelo do Fora" diferencia-se, por sua vez, do que em outros tempos levou o nome de mania, insensatez, desatino, afirma Pelbart. E prossegue, aprofundando Foucault:

Trata-se da hipótese de que o surgimento da própria loucura enquanto fato social, objeto de exclusão, de internamento e de intervenção, já teria representado o encobrimento e o desvanecimento de uma forma de alteridade todavia extrema e irredutível - a Desrazão. ${ }^{29}$

No caso de "Darandina", a desrazão, assim entendida como o campo do Desconhecido, do Acaso, da Intensidade, do Estranho etc., parece circular entre o plano do alto, para onde migrou "nosso homem" (que teria antes sido confundido com o Secretário das Finanças Públicas...) e o patamar de baixo, em que os habitantes se "confusionavam" com tanta "folia" (palavra que não deixa de apontar para o vocábulo francês "folie" ou inglês "folly" - loucura). Para demarcar os territórios e evitar o contágio com o "desordeiro, tão subvertor e anônimo", põe-se em movimento pelos bombeiros um cordão de isolamento, como se assim o Exterior, o Fora, se confinasse na personagem autoexilada na palmeira: "Nosso rancho e adro, agora de uma largura, rodeado de cordas e policiais". ${ }^{30}$ Mas isso não impede que o narrador se dirija à multidão como também "endemoniada"...

Logo veremos que o desfecho desse conto difere, no que se refere à perspectiva comunitária, de outra narrativa, também de Primeiras estórias, "Sorôco, sua mãe, sua filha". Nela, Rosa permite que a desrazão seja acolhida pelo coletivo em rito sagrado, que nele se reconhece e se irmana. Reeditando o canto desarrazoado de mãe e filha, entregues às autoridades que as levam para longe, para o hospital psiquiátrico de Barbacena, os que ficam abraçam Sorôco, que agora sem ascendência e descendência está só (oco) e

\footnotetext{
${ }^{28}$ PELBART, Da loucura à desrazão, p. 94-95.

${ }^{29}$ Idem, p. 94

${ }^{30}$ ROSA, cit., p. 132.
} 
desamparado. Juntos entoam o que antes as mulheres cantavam. Vale a pena retomar um dos parágrafos finais para melhor contrastar as atitudes em jogo:

[...] E foi sem combinação, nem ninguém entendia o que se fizesse: todos de uma vez, de dó do Sorôco, principiaram também a acompanhar aquele canto sem razão. E com as vozes tão altas! Todos caminhando, com ele, Sorôco, e canta que cantando, atrás dele, os mais de detrás quase que corriam, ninguém deixasse de cantar. Foi o de não sair mais da memória. Foi um caso sem comparação. ${ }^{31}$

Como se pode perceber pelo trecho acima, o trânsito que a cultura mantém com o Fora tem mudado a cada época, como bem mostrou a História da loucura, de Foucault. Em "Sorôco, sua mãe, sua filha", a comunidade estabelece uma ponte com a figura das loucas, que estão a caminho da internação, justamente através do canto de desatino (referido pelo texto como "o nenhum" e possível metáfora da arte). O louco é excluído, mas a desrazão comum a todos - como espaço exterior coletivo - não desaparece com o isolamento das loucas. Segundo Pelbart, na loucura "o sujeito ficaria exposto sem proteção alguma à violência desse fora", ${ }^{32}$ enquanto as vozes da desrazão podem manter com o Fora um vai e vem e uma troca. Ainda contrastando os dois contos, em "Sorôco, sua mãe, sua filha", Guimarães Rosa parece flagrar uma passagem histórica, marcada pela modernização do sertão - pano de fundo socioeconômico das Primeiras estórias -, em que o indivíduo se desgarra de um todo que lhe dava significado. As mulheres dementes não cabem mais na estrutura familiar e social em transformação daquele povoado do interior mineiro, sendo afastadas do convívio. No entanto, a redenção final em forma de procissão tenta resgatar algum elo perdido através da epifania que o canto atualiza. Algo de profético parece reviver no canto comum, ainda que a ruptura já se tenha dado.

No caso de "Darandina", o lugar do insano está mais apartado da comunidade (ironicamente, a própria personagem se interna ou se exila na palmeira), ainda que por momentos a multidão e o louco se aproximem e se confundam, sobretudo pela visada humorística do narrador.

\footnotetext{
${ }^{31}$ Idem, p. 21

32 PELBART, cit., p. 97.
} 


\section{O delírio da linguagem}

O que se deve notar é que também o texto rosiano se desloca da norma e transgride leis retóricas e convencionais da linguagem. Só assim é possível denunciar sentidos gastos e promover o estranhamento crítico. Através do seu "deus-nos sacuda", Guimarães Rosa move signos, ideias e comportamentos congelados. Ao desvairar língua e linguagem, o autor rompe as barreiras da gramática (camisa de força das palavras) e transfigura a aparência anestesiada do mundo. Os procedimentos são inúmeros e fazem o idioma ser outro que não ele mesmo. Desse choque o leitor sai alterado. Rosa interfere no corpo significante dos vocábulos e no arranjo sintático das frases, além de desconstruir clichês para libertar a forma de suas fôrmas.

Os exemplos são inúmeros: "O feio está ficando coisa", diz o narrador diante do inusitado dos fatos. E mais adiante: "cão que ladra não é mudo", sobressaltando leitores desavisados. O uso de palavras-valise, como "perséquito" (perseguição + séquito) e "ultravociferado", redobra a força vocabular, enquanto outras invenções desestabilizam o senso comum. Por exemplo: "satisfatível" (obtido por uma troca de sufixo), "tresbulício" (no lugar de rebuliço) etc. O registro lúdico se expande pelo texto, podendo, inclusive, dar aspecto erudito (e cômico) a um episódio prosaico protagonizado por um homem comum. É o caso da frase "Do alto daquela palmeira, um ser, só, nos contemplava", ${ }^{33}$ referência à fala de Napoleão aos seus soldados enfileirados nas margens do Rio Nilo: "Do alto dessas pirâmides quarenta séculos vos contemplam". Equiparar o imperador francês ao alienado na árvore subverte de uma vez os lugares consagrados e atribui ao louco um caráter épico.

Para finalizar a lista, examino uma expressão que inverte ou tensiona de modo oblíquo um aforismo latino: "Minha natureza não pode dar saltos?...", pergunta-se o velho na árvore.

Natura non facit saltus, afirma em 1704, em seu New essays of human understanding, o filósofo Leibniz (1646-1716). A natureza não dá saltos, ou seja, as espécies não são isoladas, estão sempre interconectadas, o que parece ser negado no conto: é possível, sim, estar isolado da espécie e também dar saltos sobre a racionalidade, destronando a razão. Novamente, o erudito se encontra com o popular na obra rosiana, eliminando falsas fronteiras.

${ }^{33}$ ROSA, cit., p. 133. 
Chegamos, por fim, à última peripécia do conto.

Em precário equilíbrio se sustenta o desajuizado homem, até que a população mostra sua "alucinação de manicomiáveis", como se o sujeito na palmeira tivesse, diz o narrador, "instilado veneno nos reservatórios da cidade". ${ }^{34}$

Enquanto o povo enlouquece, ocorre a inversão maior do conto: o homem desperta de sua crise "dessonambulizado", "em equilíbrio de razão: isto é, lúcido, nu, pendurado". Ou ainda: "Aquele pobre homem descoroçoava. E tinha medo e tinha horror - de tão novamente humano". ${ }^{35}$

Quando o homem retorna à "doença consciência", pois "a precisão de viver vencia-o", lá embaixo "ínfima, louca, em mar, a multidão: infernal, ululava". ${ }^{36} \mathrm{~A}$ inversão bakhtiniana se consuma e intercambiam seus postos a razão e a demência, em paralelo ao conto de Machado. Somente quando o homem é descido por cordas e tábuas, misturando-se aos demais, é que as diferenças se diluem: "Ninguém poderia deter ninguém, naquela desordem do povo pelo povo. Tudo se desmanchou em andamento, espraiando-se para trivialidades. Vivera-se o dia. Só restava imudada, irreal, a palmeira". ${ }^{37}$

O homem humano, parece dizer Rosa, é a própria travessia entre ser e não ser são ou louco. Mas se congelarmos as posições viveremos os extremos de modo alucinado. O perigo está na absolutização dos polos, na fixidez da vida.

Se em Machado não há qualquer fé na aprendizagem dos homens, sendo o epílogo de "O alienista" o triste fim de Bacamarte e o silenciamento da loucura, em "Darandina" o campo da anormalidade reedita, em chave cômica, o topos sagrado da loucura, tal como era vivida na antiguidade e também estudada por Foucault - ainda que com menos força do que no conto de Sorôco. Ela é um saber que aterroriza e fascina, diz o filósofo. Ela nos confronta e nos irmana, desde que possa ser ouvida. É verdade que, para que houvesse, no conto, alguma escuta da insensatez extraordinária do louco foi preciso erguê-lo para fora do senso comum dos demais habitantes. Ele passa, então, a emitir juízos sapienciais desconectados da norma convencional. Pela surpresa e pelo estranhamento, o homem da palmeira

\footnotetext{
${ }^{34}$ ROSA, cit., p. 135.

35 Ibidem.

${ }^{36}$ Ibidem.

${ }^{37}$ Idem, p. 136.
} 
traz algo novo em seu delírio, que alguns percebem e admiram, entre eles o narrador e sua "simpatia intelectual" pelo alucinado.

Uma última visada analítica passa, necessariamente, pela cena da descida do homem pela escada. No caminho de volta, a frase anotada pelo narrador é: nu, adão, nado, psiquiartista. ${ }^{38}$ Entre o polo ascensional das alturas e o plano terrestre, parece haver um espaço intermédio para a nudez sem máscaras (nu), para a reinvenção adâmica do mundo (adão), para o ilógico (nado) e, por fim, para uma invenção linguística dada pelo sugestivo neologismo (psiquiartista), que mostra ser a arte um lugar de encontro possível para uma "psique do Fora". Os poetas loucos, diria Foucault, expressam a desrazão com as máscaras que a época lhes emprestou: a arte e a loucura. Aqui, simbolicamente, é na passagem da loucura para a convenção (mundo administrado do cotidiano, para o qual o homem desce) que o termo "psiquiartista" é usado, forma lúdica e quase paranomástica, de se referir, também ao campo da psiquiatria.

A arte, então, habitaria essa soleira entre mundos. Do ponto de vista da psicanálise, a arte estaria situada na transformação das fantasias pessoais por procedimentos de atenuação de conteúdos primários e de realização estética. Para Freud, o artista (ou "psiquiartista"?) gratifica-se na expressão artística do mesmo modo que o seu público, uma vez que as forças motivadoras da obra são conflitos com os quais todos nos identificamos. Portanto, o modo como Rosa aproximou, no final do conto, a arte da loucura, trazendo a face artística do louco justamente na passagem, no limiar entre a pura imaginação (elevação da palmeira) e a vida da realidade cotidiana, poderia nos remeter à afirmação de Freud de que a arte

[...] constitui um meio-caminho entre uma realidade que frustra os desejos e o mundo de desejos realizados da imaginação - uma região em que, por assim dizer, os esforços de onipotência do homem primitivo ainda se acham em pleno vigor. ${ }^{39}$

Pontes, limiares e travessias são signos bem conhecidos do universo rosiano. Já Machado, descrente de qualquer redenção, narra de fora uma crônica de Itaguaí e faz da distância em relação às suas personagens o lugar onde a ironia crítica se instala. Rosa, por sua vez, atravessado pela religiosidade

${ }^{38}$ Ibidem, grifos do autor.

${ }^{39}$ FREUD, O interesse científico pela psicanálise, p. 223. 
popular, ${ }^{40}$ dá voz a um narrador testemunha, que mostra empatia com o homem das alturas e dele se compadece como se estivesse diante de um menino.

Por isso, talvez, o título "Darandina". "Dandar" quer dizer "andar como criança que está aprendendo a andar". ${ }^{41} \mathrm{O}$ verbo aparece conjugado e transfigurado na sua forma dicionarizada: "Dandinava." 42 Loucos e crianças trazem o sopro de uma origem perdida desde sempre, a qual só podemos escutar em seus sussurros ou sobressaltos. Tendo antes avizinhado a loucura à arte, agora Rosa a aproxima da infância. No encontro de ambas, gera-se uma nova forma de conhecimento:

Esse saber, tão inacessível e temível, o Louco o detém em sua parvoíce inocente. Enquanto o homem racional e sábio só percebe desse saber algumas figuras fragmentárias - e por isso mesmo mais inquietantes -, o Louco o carrega inteiro em uma esfera intacta: essa bola de cristal, que para todos está vazia, a seus olhos está cheia de um saber invisível. ${ }^{43}$

Saber inocente e invisível, só apreensível na arte do psiquiartista. Afinal, como afirma o dr. Bilolô, "a vida é constante, progressivo desconhecimento".

\section{Referências}

ASSIS, Machado de. O alienista. In: Obra completa. Rio de Janeiro: Nova Aguilar, 1994, vol. II.

BOSI, Alfredo. Machado de Assis: O enigma do olhar. São Paulo: Ática, 1999.

FOUCAULT, Michel. História da loucura na Idade Clássica. São Paulo: Perspectiva, 1978.

FREUD, Sigmund. Obras psicológicas completas. Rio de Janeiro: Imago, 1969.

HOLANDA, Aurélio Buarque de. Pequeno dicionário brasileiro da língua portuguesa. Rio de Janeiro: Civilização Brasileira, 1961.

HOMEM, Maria Lúcia. Reflexos de espelhos. Machado de Assis e Guimarães Rosa: um estudo comparativo. Disponível em: http://www.oocities.org/hotsprings/villa/3170/MariaLuciaHomem.htm. Acesso em: 18 mar. 2012.

\footnotetext{
${ }^{40}$ Ver a respeito BOSI, Céu, inferno, p. 10-32.

${ }^{41}$ Cf. MARTINS, O léxico de Guimarães Rosa.

42 "'Dandinar': andar balançando desgraciosamente o corpo". HOLANDA, Pequeno dicionário brasileiro da lingua portuguesa, p. 360 .

${ }^{43}$ FOUCAULT, cit., p. 21.
} 
LEIBNIZ, Gottfried Wilhelm. New Essays on Human Understanding. Translated and edited by Peter Remnant and Jonathan Bennett. Cambridge: Cambridge University Press, 1981.

LIMA, Luiz Costa. O palimpsesto de Itaguaí. In: Pensando nos trópicos. Rio de Janeiro: Rocco, 1991.

MARTINS, Nilce Sant'Anna. O léxico de Guimarães Rosa. São Paulo: Edusp, 2001.

MEYER, Augusto. Na casa verde. In: Machado de Assis. Rio de Janeiro: José Olympio, 1958, p. 42-48.

MEZAN, Renato. Freud pensador da cultura. 5. ed. São Paulo: Brasiliense, 1990.

OLIVEIRA, Luis Claudio Vieira de. Guimarães Rosa leitor de Machado. O Eixo e a Roda: Revista de Literatura Brasileira. Belo Horizonte, vol. 7, p. 79-91, maio 2001.

Disponível em:

http://periodicos.letras.ufmg.br/index.php/o_eixo_ea_roda/article/view/3097.

Acesso em: 29 out. 2016.

ORSINI, Cecília Maria de Brito. Nós, os alienistas. Disponível em: http://estudosdefreud.com.br/alienista/.

PELBART, Peter Pál. Da loucura à desrazão. In: A nau do tempo-rei: sete ensaios sobre o tempo da loucura. Rio de Janeiro: Imago, 1993, p. 90-99.

PERRONE-MOISÉS, Leyla. Para trás da Serra do Mim. Scripta. Edição Especial do II Seminário Internacional Guimarães Rosa. Rotas e Roteiros. Revista do Programa de Pós-Graduação em Letras e do Cespuc, v. 5, n. 10, $1^{\circ}$ sem. 2002.

ROSA, João Guimarães. Primeiras estórias. Rio de Janeiro: Nova Fronteira, 1988.

ROSENBAUM, Yudith. Guimarães Rosa: O canto da desrazão. Ângulo, Fatea, out./dez. 2008, n. 115, p. 150-158.

Disponível em: http://www.fatea.br/seer/index.php/angulo/article/view/111/97.

WISNIK, José Miguel. Psiquê e Psichê: No encontro dos espelhos. In: PASSOS, Cleusa Rios; ROSENBAUM, Yudith. (Orgs.). Interpretações. Crítica literária e Psicanálise. Cotia, SP: Ateliê Editorial, 2014, p. 141-167.

YUDITH ROSENBAUM é professora de literatura brasileira na Faculdade de Letras da FFLCH-USP. Sua linha de pesquisa é a interface da literatura com a psicanálise, com foco em autores do século XX: Mário de Andrade, Guimarães Rosa, Manuel Bandeira e Clarice Lispector. Publicações recentes: Interpretações. Crítica literária e literatura comparada. Orgs. Cleusa Rios Passos e Yudith Rosenbaum. Cotia: Ateliê Editorial, 2014; "O eu tornado outro: o estranhamento em PSGH e A quinta história de Clarice Lispector". Revista El Hilo de la Fábula. Universidad del litoral, Santa Fé (Argentina), 2015, p. 48-58; "Uma estranha descoberta: uma leitura de 'A menor mulher do mundo, de Clarice Lispector'". Literatura e Sociedade, DTLLC/USP, 2015, p. 148-156. E-mail: yudith@uol.com.br. 